\title{
Effect of salinity on the physiology of peanut variety 73-33 (Arachis hypogaea L.)
}

\author{
Adiouma Dangue ${ }^{1,}{ }^{*}$, Bathie Sarr ${ }^{1}$ and Ibrahima Kane ${ }^{2}$ \\ ${ }^{1}$ Department of Plant Biology, Mushroom Biotechnology Laboratory, Faculty of Science and Technology, Cheikh Anta \\ Diop University of Dakar, Dakar BP 5005, Senegal. \\ ${ }^{2}$ Department of Live Sciences and Earth, Faculty of Sciences and Technologies Education and Training, Cheikh Anta Diop \\ University of Dakar, Dakar BP 5005, Senegal.
}

GSC Biological and Pharmaceutical Sciences, 2021, 17(01), 001-010

Publication history: Received on 20 August 2021; revised on 28 September 2021; accepted on 30 September 2021

Article DOI: https://doi.org/10.30574/gscbps.2021.17.1.0285

\begin{abstract}
Peanut (Arachis hypogaea, L.) is an annual papilionaceous oilseed legume cultivated on nearly 25 million hectares in tropical and temperate zones due to its remarkable plasticity to temperature and water requirements. In Senegal, peanut is produced in rural areas where they are the main source of agricultural income. Variety 73-33 is cultivated in the river valley and the groundnut basin is subject to the influence of salinization affecting four of Senegal's ecogeographic zones.

Studies conducted with randomized full-block experimental set-up in the laboratory and under semi-controlled greenhouse conditions have shown the effect of different concentrations of $\mathrm{NaCl}$ on the peanut variety 73-33: $0 \mathrm{mM}$; $25 \mathrm{mM} ; 50 \mathrm{mM} ; 100 \mathrm{mM} ; 200 \mathrm{mM} ; 300 \mathrm{mM} ; 400 \mathrm{mM} ; 500 \mathrm{mM}$ for germination and $0 \mathrm{mM} ; 25 \mathrm{mM} ; 50 \mathrm{mM} ; 100 \mathrm{mM}$ for growth growth and chlorophyll production. The parameters which were measured are: the germination rate (ten days after sowing), the number of nodules, the number of gynophores, the dry biomass and the production of chlorophyll at twenty, forty and seventy-five days after sowing.
\end{abstract}

Germination is significantly negatively affected from $400 \mathrm{mM}$.

Twenty days after sowing there is a significant difference between the control and the other treatments for the production of chlorophyll a (Chla) only.

Forty days after sowing, the production of chlorophyll a and total chlorophyll shows a very highly significant difference between all the treatments. The dry biomass only shows a significant difference from $100 \mathrm{mM}$.

Seventy-five days after sowing, the dry biomass and the number of gynophores are significantly reduced by the salinity from $25 \mathrm{mM}$.

Keywords: Peanut; Chlorophyll; Growth; Germination; $\mathrm{NaCl}$

\section{Introduction}

Groundnut or ground pistachio (Arachis hypogaea, L.) is an annual papilionaceous oilseed legume that grows in hot countries [1]. It is cultivated over an area of nearly 25 million hectares throughout the tropics and in temperate zones up to $40^{\circ} \mathrm{C}$ North latitude thanks to its remarkable plasticity in the face of temperatures and water requirements. Africa

\footnotetext{
${ }^{*}$ Corresponding author: Adiouma Dangue

Department of Plant Biology, Mushroom Biotechnology Laboratory, Faculty of Science and Technology, Cheikh Anta Diop University of Dakar, Dakar BP 5005, Senegal.
}

Copyright (c) 2021 Author(s) retain the copyright of this article. This article is published under the terms of the Creative Commons Attribution Liscense 4.0. 
provides $25 \%$ of its production mainly from Nigeria, Senegal and Sudan. In Senegal, it is cultivated on nearly one million hectares [2]. Produced for its agronomic and food interests, it is the main source of income, especially economic in rural areas ([2]; [3]). Many varieties are cultivated in Senegal [4]. Among these, variety 73-33 of type Virginia, resistant to drought, to Aspergillus flavus (aflatoxin), plastic and slightly dormant. Its cycle is 105 days [5]. This variety is one of the best among the main groundnut varieties grown in West Africa. It can be used as a peanut for food or in confectionery; its thousand-seed weight is greater than $50 \mathrm{~g}$ [6].

It is used in rainfed and irrigated crops in the river valley and the groundnut basin [5] and subject to the influence of salinization affecting four of the ecogeographic zones of Senegal [7].

Salinization is a brake on their agricultural development [8], and one of the causes of the drop in agricultural production [9] which affects more than one million hectares of Senegambian lands. It is caused by various types of salt ( $\mathrm{Na}_{2} \mathrm{~S} 04$, $\mathrm{MgSO}_{4}$, etc.), but especially by sodium chloride $(\mathrm{NaCl})$, one of the main abiotic stresses that inhibit plant growth and reduce their productivity [10].

Indeed, when salty soils if they contain $40 \mathrm{mM}$ of $\mathrm{NaCl}$ or if their electrical conductivity is greater than $4 \mathrm{dS}$ m-1 or if their osmotic potential is less than $0.117 \mathrm{MPa}$, they have a degraded structure, a low porosity and a pH high (>8) ([11]; [12]). The plants that develop on these soils are subjected to physiological drought and have a very low root osmotic potential (around -100 bars) [11] leading to an inhibition of their growth and a reduction in their productivity [10].

In Senegal, the salinity is estimated at $9 \%$ in the Niayes, $20 \%$ in the groundnut basin, between 26 and $37 \%$ in eastern Senegal, between 36 and 53\% in Casamance to reach a maximum of 66\% in the River region [13].

In this study our objective is to know under semi-controlled conditions the effect of the salinity due to $\mathrm{NaCl}$ on the peanut variety 73-33.

\section{Material and methods}

\subsection{Plant material}

The plant material consists of seeds of the peanut variety 73-33. The seeds are disinfected with $5 \%$ sodium hypochlorite for 2 minutes and then rinsed three times with sterile distilled water. They are sown in Petri dishes on tissue paper moistened with $10 \mathrm{ml}$ of the corresponding solution. A seed is considered germinated when there has been emergence of the radicle [14].

\subsection{Experimental apparatus}

A first experimental device randomized to an abiotic constrained factor ( $\mathrm{NaCl})$ with eight modalities $(0 \mathrm{mM} ; 25 \mathrm{mM} ; 50$ $\mathrm{mM}$; $100 \mathrm{mM} ; 200 \mathrm{mM} ; 300 \mathrm{mM} ; 400 \mathrm{mM}$ and $500 \mathrm{mM}$ ) is used to evaluate the effect in vitro of salinity on peanut germination.

The second device, a randomized full-block experimental set-up with a four-modality (T0 = $0 \mathrm{mM}$; $\mathrm{T} 1=25 \mathrm{mM}$; $2=50$ $\mathrm{mM}$; T3 = $100 \mathrm{mM}$ ) abiotic stress factor $(\mathrm{NaCl})$, is used to determine the effect of salinity on plant growth and chlorophyll production.

In both devices, each treatment is repeated three times.

\subsection{Soil sample}

The experimental unit was represented by a pot containing $1.5 \mathrm{~kg}$ of substrate. The substrate used is the soil of the botanical garden of the Faculty of Sciences and Techniques of the University Cheikh Anta Diop in Dakar, the characteristics of which are defined (Table 1). 
Table 1 Physicochemical characteristics of the soil used

\begin{tabular}{|l|l|}
\hline pH eau 1 / 1,25 & 7.4 \\
\hline CE 1 / 10 $\mathbf{~ s / c m ~}$ & 65 \\
\hline \% C & 2.37 \\
\hline \% MO & 4.086 \\
\hline \% N & 0.21 \\
\hline C / N & 11 \\
\hline Ca meq / 100 g & 6.9 \\
\hline Mg meq / 100 g & 0.525 \\
\hline Na meq / 100 g & 0.0425 \\
\hline K meq / 100 g & 0.139 \\
\hline P ppm & 48 \\
\hline S meq / 100 g & 7.606 \\
\hline CEC meq / 100 g & 15 \\
\hline T \% & 51 \\
\hline PSE \% & 0.3 \\
\hline A \% & 10.75 \\
\hline LF \% & 2.5 \\
\hline LG \% & 1.29 \\
\hline SF \% & 48.3 \\
\hline SM \% & 36.66 \\
\hline SG \% & 0.485 \\
\hline \% & 6 \\
\hline
\end{tabular}

T: rate of base saturation; PSE: Percentage of Exchangeable Sodium; A: clay; LF: fine silt; LG: coarse silt; SF: fine sand; SM: medium sand; SG: coarse sand.

\subsection{Culture mode}

Three seeds are sown in each pot. The pots are sprayed with tap water for up to 10 days after emergence.

For each pot the best plant was kept. The saline treatment is applied from the tenth after the emergence of the seedlings. Watering to capacity in the field [15] is done every 3 days with the corresponding solutions. Three harvests were made, the first at the end of the growth phase 20 days after sowing (20 DAS), the second at the end of the flowering phase 40 days after sowing (40 DAS) and the last at 75 days after sowing ( 75 DAS) corresponding to the start of maturity for the earliest varieties [16].

\subsection{Parameters measured}

The final germination rate is evaluated after 10 days for laboratory experimentation.

At the third harvest (75 days after sowing), the number of gynophores and the number of nodules per plant were counted.

The mass of dry matter obtained after drying in an oven at $70^{\circ} \mathrm{C}$ for 48 hours ([17]; [15]) is measured with a precision balance $(400 \pm 0.001 \mathrm{~g})$. The number of leaves on the main stem and the number of branches were counted for each plant. 
The chlorophyll content is estimated based on the Arnon method [18] ; a mass of 100 mg of fresh plant material (leaves) was ground with $10 \mathrm{ml}$ of $80 \%$ acetone, the ground material was centrifuged at 4000 revolutions / minute for five minutes. The supernatant which contains the pigments is recovered. Optical densities are read at wavelengths $645 \mathrm{~nm}$ and $663 \mathrm{~nm}$. The chlorophyll content is determined according to the Arnon [18] equations:

$$
\begin{aligned}
& \text { Chl a }(\mathrm{mg} / \mathrm{gFW})=12.7 \times \text { DO }(663)-2.69 \times \mathrm{DO}(645)(\mathrm{mg} / \mathrm{gFW})(\text { Equation } 1) \\
& \text { Chl b }(\mathrm{mg} / \mathrm{gFW})=22.9 \times \text { DO }(645)-4.68 \times \text { DO }(663)(\mathrm{mg} / \mathrm{gFW})(\text { Equation } 2) \\
& \text { Chl }(\mathrm{mg} / \mathrm{gFW})=\text { Chla }+ \text { Chlb }=20.2 \times \text { DO }(645)+8.02 \times \text { DO }(663)(\mathrm{mg} / \mathrm{gFW})(\text { Equation } 3)
\end{aligned}
$$

\subsection{Statistical analyzes}

Statistical analyzes were performed with R software version 3.6 .3 (2020-02-29). All data is subjected to the ShapiroWilk normality test. Statistical processing of normally distributed data is performed by adopting a parametric approach with analysis of variance (ANOVA). For data with non-normal distribution, a non-parametric approach is applied with an analysis of variance on the ranks of the means. The Tukey test at the $5 \%$ probability threshold is performed in order to compare and rank the means or ranks on the means of the variables evaluated.

\section{Results}

\subsection{Effect of salinity on germination of peanut}

The germination rate (TR) of peanut variety $73-33$ is not affected by salinity up to $200 \mathrm{mM} \mathrm{NaCl}$ and is $100 \%$. Between 200 and $300 \mathrm{mM}$, a slight decrease is observed without this translating into a significant difference. From $300 \mathrm{mM}$ the level decreases to cancel out at $500 \mathrm{mM}$ (Figure 1).

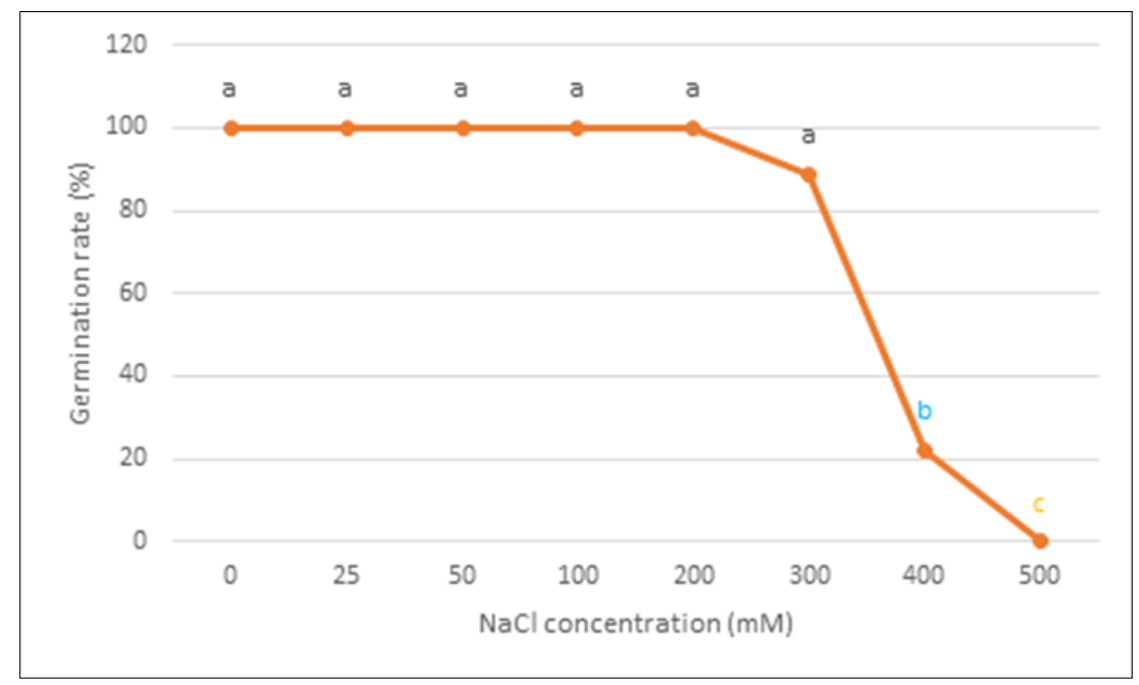

Figure 1 Effect of salinity on the germination rate of peanut variety 73-33

The same letter indicates that there is no significant difference at the $5 \%$ level on the Student-Newman-Keuls test (SNK).

\subsection{Effect of salinity on dry biomass}

The mass of dry matter decreases with salinity, especially at 75 DAS. No significant difference was observed for this mass of dry matter at twenty days after sowing (20 DAS) unlike the 75th DAS where a difference was observed between all the concentrations. A significant difference is noted forty days after sowing (40 DAS) between the biomass at 100 $\mathrm{mM}$ and that of the other treatments (Figure 2).

The mass of dry matter of the control $(0 \mathrm{mM})$ is greater and that of the treatment with the greatest concentration of $\mathrm{NaCl}(100 \mathrm{mM})$ is the lowest whatever the harvest date. The dry biomass (DB) of peanut variety 73-33 decreased with increasing salt $(\mathrm{NaCl})$ content (Figure 2). 


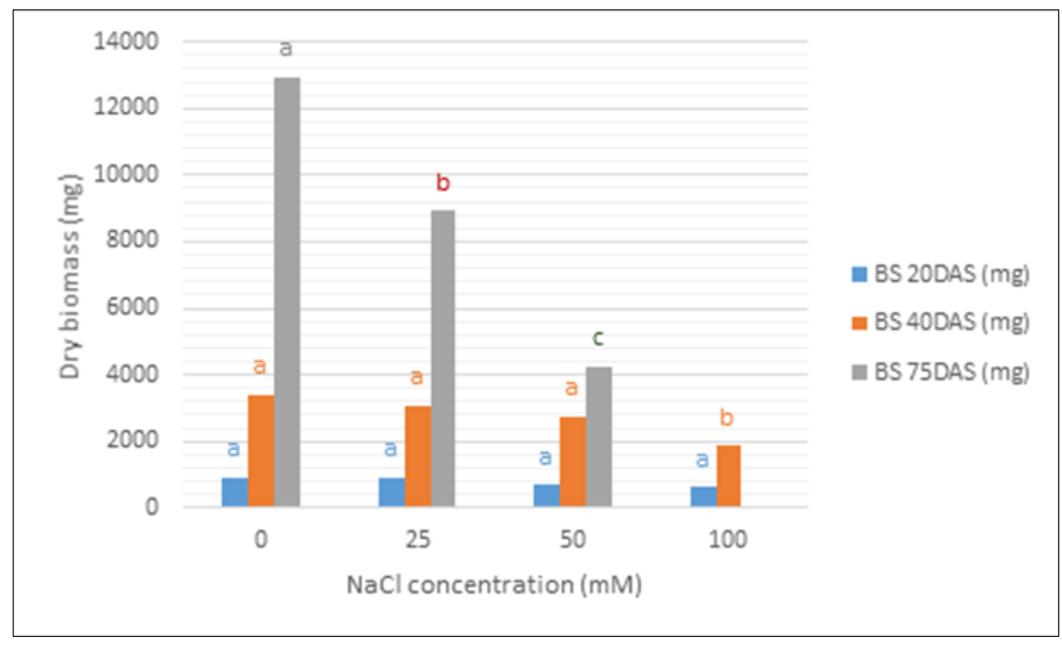

Figure 2 Effect of salinity on dry biomass in peanut variety 73-33 at 20 DAS, 40 DAS and 75 DAS Dry biomass (DB), twenty days after sowing (20DAS), forty days after sowing (40DAS), seventy-five days after sowing (75DAS) The bars followed by the same letter are not significantly different at the $5 \%$ level on the Student-Newman-Keuls test (SNK).

\subsection{Effect of salinity number of gynophores and nodules}

The number of gynophores and nodules of the plants of the peanut variety 73-33 decreased respectively from 13 to 1 and 12 to 4 with the increase in the concentration of $\mathrm{NaCl}$ without this translating into significant differences for the plants. $25 \mathrm{mM}$ and $50 \mathrm{mM} \mathrm{NaCl}$ concentrations relative to the control. For the number of nodules there is no significant difference (figure 3).

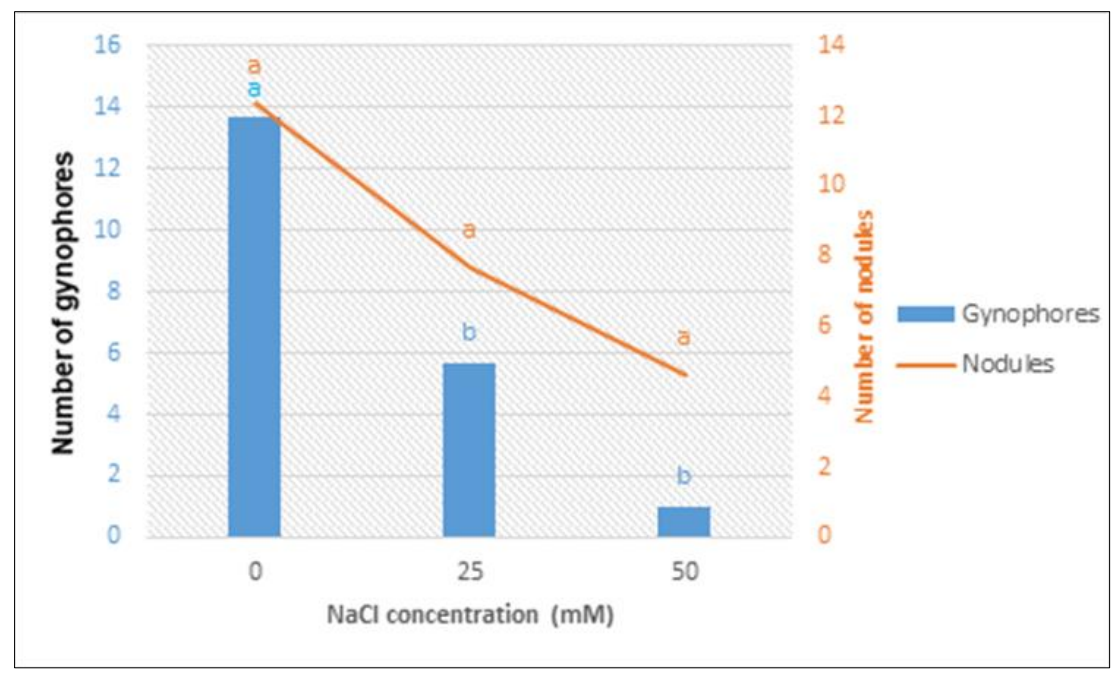

Figure 3 Effect of salinity on the number of gynophores and nodules in the peanut variety 73-33 to 75 DAS Seventy-five days after sowing (75DAS).

The same letter indicates that there is no significant difference at the 5\% level on the Student-Newman-Keuls test (SNK).

\subsection{Effect of salinity on chlorophyll}

The amount of chlorophyll (Chla, Chlb, Chl) in plants of the peanut variety 73-33 decreased from 0.85 to $0.47 \mathrm{mg} / \mathrm{g}$ and 3.38 to $2.49 \mathrm{mg} / \mathrm{g}$ with increasing of the $\mathrm{NaCl}$ concentration (amount of $\mathrm{NaCl}$ in the irrigation water) at $20 \mathrm{JAS}$ and 40 DAS respectively (Figures 4 to 6 ).

On the other hand at 75 JAS, the quantity of chlorophyll increased from 1.08 to $1.20 \mathrm{mg} / \mathrm{g}$ with salinity (Figure. 4). The amount of chlorophyll is lower at 20 JAS but is higher at 40 JAS regardless of the $\mathrm{NaCl}$ concentration (Figures 4 to 6 ). 


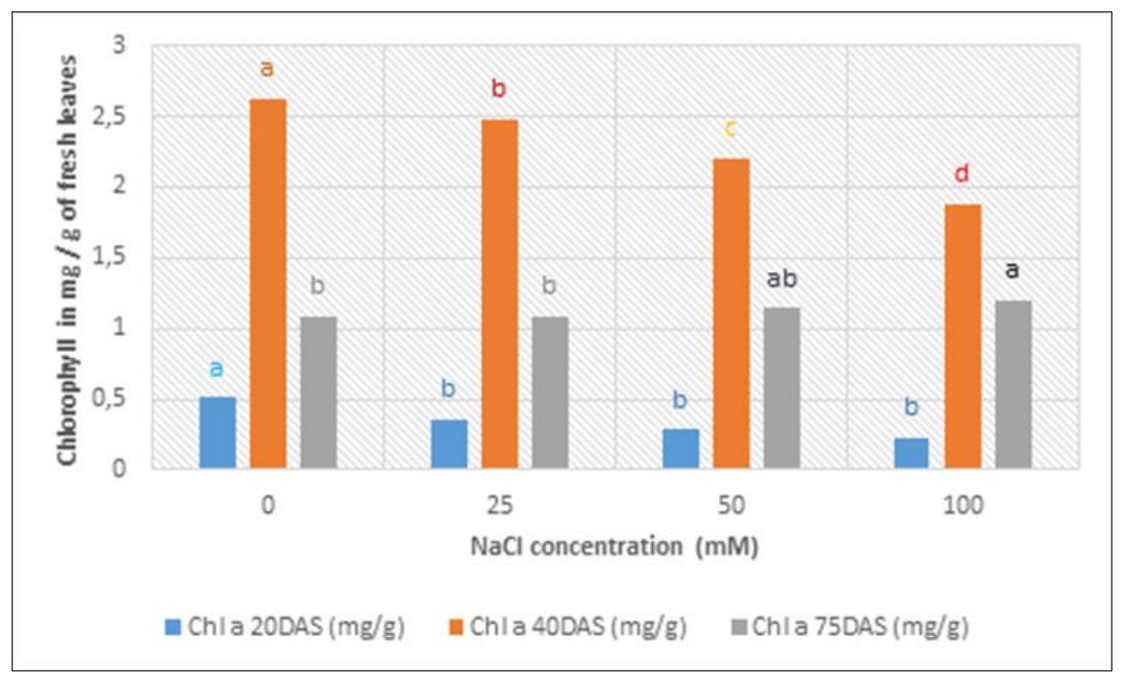

Figure 4 Effect of salinity on the amount of chlorophyll a in the peanut variety 73-33 at 20 DAS, 40 DAS and 75 DAS Chlorophyll a (Chla), twenty days after sowing (20DAS), forty days after sowing (40DAS), seventy-five days after sowing (75DAS). The bars followed by the same letter are not significantly different at the $5 \%$ level on the Student-Newman-Keuls test (SNK)

The quantity of chlorophyll a (Chla) is greater than that of chlorophyll b (Chlb) regardless of the date of harvest (Figures 4 and 5). Statistical analysis does not show a significant difference for the total chlorophyll (Chl) and chlorophyll b (Chlb) of the plants of the different treatments at each of the harvests on dates 20 JAS and 75 JAS (Figures 4 and 5). However, chlorophyll a (Chla) shows significant differences between the control and the other treatments at 20 DAS and between all the treatments except the control and the lowest concentration $(25 \mathrm{mM} \mathrm{NaCl})$ at $75 \mathrm{DAS}$ (Figure 4).

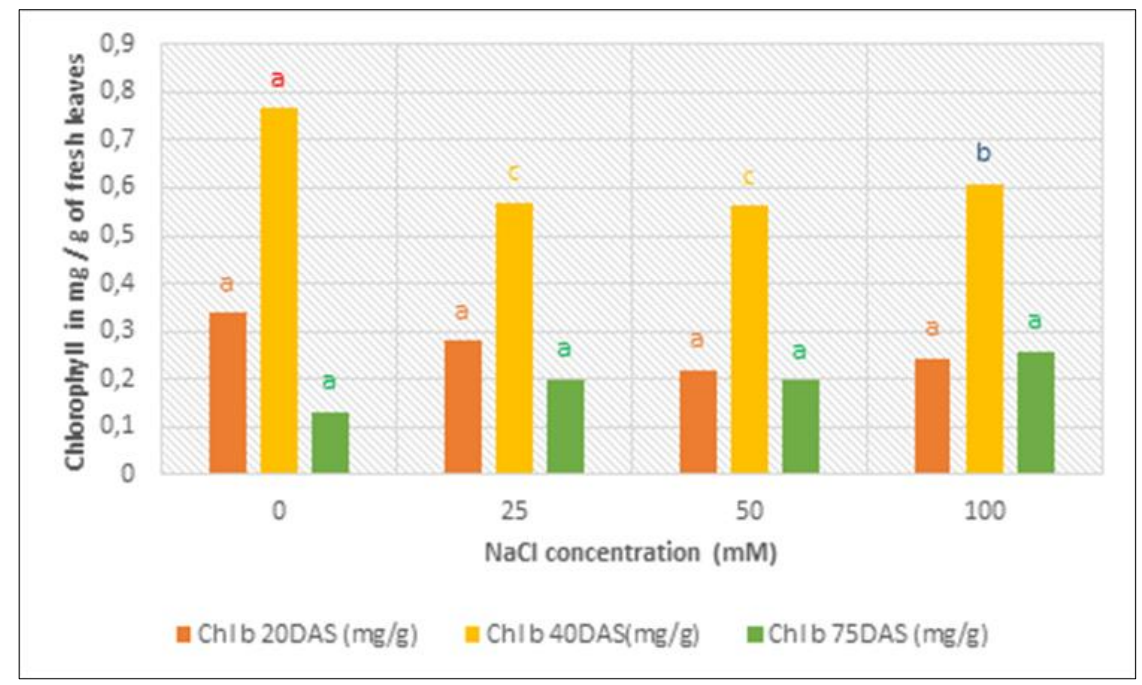

Figure 5 Effect of salinity on the amount of chlorophyll b in the peanut variety 73-33 at 20 DAS, 40 DAS and 75 DAS Chlorophyll b (Chlb), twenty days after sowing (20DAS), forty days after sowing (40DAS), seventy-five days after sowing (75DAS). The bars followed by the same letter are not significantly different at the $5 \%$ level on the Student-Newman-Keuls test (SNK). 


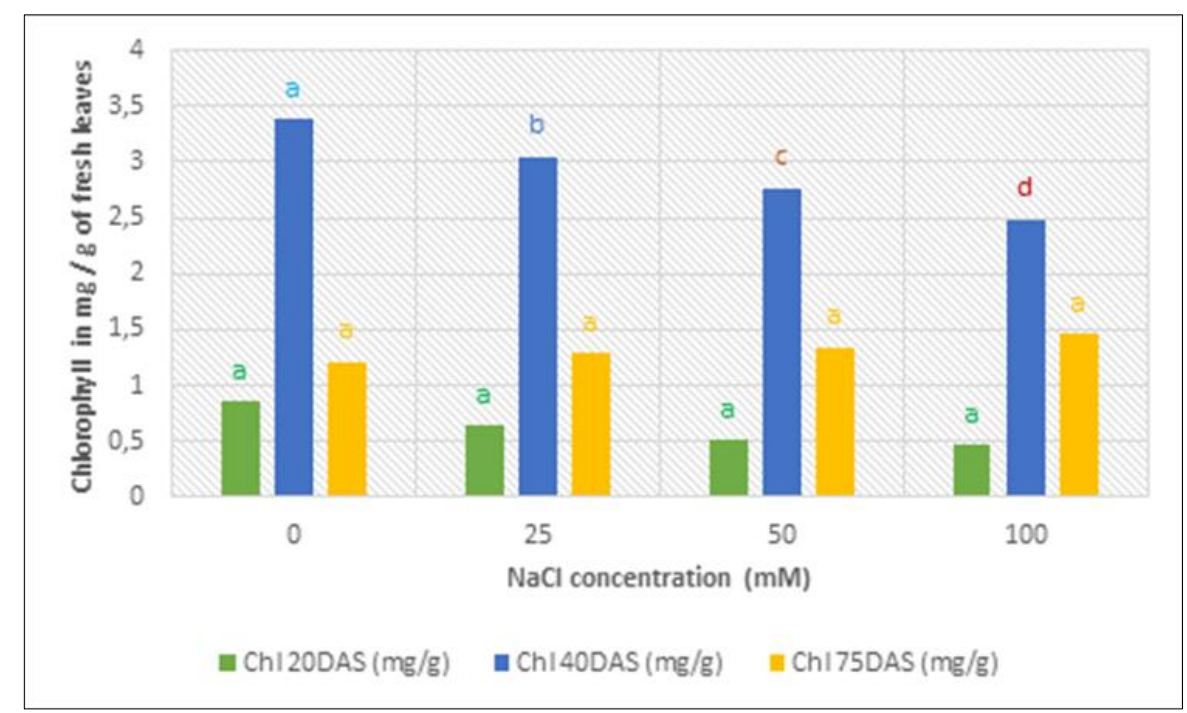

Figure 6 Effect of salinity on the amount of total chlorophyll in the peanut variety 73-33 at 20 dAS, 40 DAS and 75 DAS Total chlorophyll (Chl), twenty days after sowing (20DAS), forty days after sowing (40DAS), seventy-five days after sowing (75DAS). The bars followed by the same letter are not significantly different at the $5 \%$ level on the Student-Newman-Keuls test (SNK).

\section{Discussion}

The germination rate (TR) of peanut variety 73-33 is not affected by salinity for concentrations less than or equal to 200 $\mathrm{mM} \mathrm{NaCl}$, it is $100 \%$. From $300 \mathrm{mM}$, there is a decrease in the germination rate as a function of the salinity (figure 1). These results are in agreement with those of Ndiaye et al. [9] who showed a decrease in the final germination percentage in Gossypium hirsutum L. with increasing salinity. The germination rates at the concentrations $400 \mathrm{mM}$ and $500 \mathrm{mM}$ show a significant difference between them and also with those of the concentrations less than or equal to $300 \mathrm{mM}$. These results agree with those of Dangue et al. [19] who showed a significant reduction in the germination rate as a function of salinity in sesame (Sesamum indicum L.).

The dry biomass (BS) of peanut variety 73-33 decreased with increasing salt $(\mathrm{NaCl})$ content over the harvest date (Figure 2). This negative effect of $\mathrm{NaCl}$ on dry biomass has been noted in various species such as roselle [20], wheat [21], chili [22], cowpea (Phaseolus vulgaris L.) [23], sesame ([19]; [24]; [25]). This reduction may be related to the toxic effect of $\mathrm{Cl}^{-}$and $\mathrm{Na}^{+}$ions accumulated in the tissues ([26]; [27]). The effects of salinity are manifested mainly by slowing the growth of the vegetative system [15]. This slowing down may explain the decrease in dry biomass with increasing salinity. Bekele et al. [28] claim that salinity causes morphological, physiological, biochemical and molecular changes negatively affecting plant growth and metabolism. However, according to these authors crops react differently to salinity and some can be tolerant.

The increased salinity resulted in a reduction in the number of gynophores in plants of the peanut variety 73-33 (Figure 3). Statistical analysis only shows a significant difference in the number of gynophores for the $25 \mathrm{mM}$ and $50 \mathrm{mM} \mathrm{NaCl}$ concentrations compared to the control.

These results are consistent with those of Srivastava et al. [29], which showed a significant reduction in the number of gynophores due to soil salinity.

The number of nodules at the level of the roots of plants of the peanut variety 73-33 decreases according to the salinity but does not show any significant difference (Figure 3). These results agree with those of Tegger [30] and Saadallah et al. [31] who observed, respectively, a decrease in the number of nodules in lentil (Lens culinaris L.) and in beans (Phaseolus vulgaris L.) proportional to the intensity of the salt stress applied. Similar results are also obtained in beans. According to Saadallah et al. [31], the reduction in the number of nodules is linked to a decrease in the potential sites of infection resulting mainly from an inhibition of the emergence and elongation of root hairs and of the growth of the root system in general. Shahid et al. [32] showed a depressive effect of salinity on the number of nodules in Vigna radiata inoculated with halotolerant bacteria.

Chlorophyll a is more affected by salinity than chlorophyll $b$ in peanut variety 73-33 (Figures 4 and 5). The greatest reduction in chlorophyll a may be related to the sensitivity of one of the steps in its biosynthesis to sodium chloride 
[33]. However, Gomes et al. [34] showed greater tolerance to the salinity of chlorophyll a in Salvinia auriculata Aubl., An aquatic fern. Thouraya et al. [22] obtained similar results in chili (Capsicum annuum L). The depressive effect of salinity is more pronounced on chlorophyll a than on chlorophyll b ([35]; [36]). This is explained by a greater sensitivity of the biosynthesis of chlorophyll a to sodium chloride ([35]; [37]). The amounts of chlorophyll in peanut variety 73-33 decreased with increasing salinity (Figures 4, 5, 6). These results are consistent with those of Al-Khaliel [38] who did not observe a significant difference, in peanuts, between the amounts of chlorophyll as a function of salinity. This reduction of chlorophyll by salinity has been obtained in tomato [33], peanuts [38], banana [35], chili [22] and cowpeas (Phaseolus vulgaris L.) [23]. Salinity induces nutritional disorders causing damage to macromolecules such as chlorophyll due to loss of membrane integrity and photosynthetic activity [39]. This reduction in chlorophyll is explained by the stimulation of the enzymatic activity of chlorophyllase by salinity [40]. It can be due to the destruction of the precursors of chlorophyll, to the conversion of the latter to other pigments or to the decrease in the accumulation of $\mathrm{Mg}$, an integral component of photosynthetic pigments, to the destruction of the fine structure of chloroplasts or instability of the pigment-protein complex [41]. This reduction in chlorophyll may also be linked to the sensitivity of its biosynthesis to $\mathrm{NaCl}$ [37]. Salinity also induces nutritional disorders causing damage to macromolecules such as chlorophyll due to loss of membrane integrity and photosynthetic activity [39]. NaCl also reduces the activity of chlorophyll by inhibiting the synthesis of 5-amino-levulinic acid or by occupying the site of action of nitrogen (N), an essential component of chlorophyll ([22]; [37]).

\section{Conclusion}

The effect of different concentrations ( $0 \mathrm{mM}, 25 \mathrm{mM}, 50 \mathrm{mM}, 100 \mathrm{mM}, 200 \mathrm{mM}, 300 \mathrm{mM}, 400 \mathrm{mM}$ and $500 \mathrm{mM})$ of $\mathrm{NaCl}$ on the germination of seeds of the peanut variety 73-33 grown in Senegal has been evaluated in vitro in the laboratory. This variety of peanut is insensitive to salinity up to $200 \mathrm{mM} \mathrm{NaCl}$ during its germination. Beyond $300 \mathrm{mM}$, its germination decreases according to the salinity. From $500 \mathrm{mM} \mathrm{NaCl}$ the seeds of this variety can no longer germinate.

The effect of different concentrations ( $0 \mathrm{mM}, 25 \mathrm{mM}, 50 \mathrm{mM}$ and $100 \mathrm{mM})$ of $\mathrm{NaCl}$ on the growth of seedlings of peanut variety 73-33 grown in Senegal was determined under semi-controlled greenhouse conditions. The amount of chlorophyll ( $\mathrm{Chl} \mathrm{a}, \mathrm{Chl} \mathrm{b}, \mathrm{Chl}$ ) of the plants of the peanut variety 73-33 decreased with the increase in the concentration of $\mathrm{NaCl}$ at 20 DAS and 40 DAS, but at 75 DAS the amount of chlorophyll increased with salinity which would be a physiological adaptation.

Dendrometric parameters such as apical growth (length of the main stem), number of leaves and number of branches are negatively influenced by salinity from $25 \mathrm{mM}$.

The salinity leads to a reduction in the number of nodules at the level of the roots and gynophores.

Dry biomass is the parameter most negatively affected by salinity.

Ultimately, this study shows that the 73-33 peanut variety cultivated in Senegal is sensitive to salinity. This sensitivity can be manifested by a reduction of the parameters studied, a decrease in the quantity of chlorophyll 40 JAS and a lethality or a reduction of the parameters studied, it depends on the stage of development of the plant.

\section{Compliance with ethical standards}

\section{Acknowledgments}

The authors the Mushroom Biotechnology Laboratory.

\section{Disclosure of conflict of interest}

Authors declare that no conflict of interest exist.

\section{References}

[1] Schilling R. Données agronomiques de base sur la culture arachidière. Oléagineux, Corps Gras, Lipides. 2001; 8(3): 230-6.

[2] Noba K, Ngom A, Guèye M, Bassène C, Kane M, Diop I, Ndoye F, Mbaye MS, Kane A, Ba AT. L'arachide au Sénégal : État des lieux, contraintes et perspectives pour la relance de la filière. OCL. 2014; 21(2): D205. 
[3] Clavel D, Drame NK, Diop ND, Zuily-Fodil Y. Adaptation à la sécheresse et création variétale : Le cas de l'arachide en zone sahélienne : Première partie : revue bibliographique. Oléagineux, Corps gras, Lipides. 2005; 12(3): 248-260.

[4] Bockelée-Morvan A. Oléagineux. Février. 1983; 38(2).

[5] Clavel D, Ndoye O. La carte variétale de l'arachide au Sénégal. Agriculture et développement. 1997; (14): 41-46.

[6] Cirad G. Mémento de l'Agronome. Nouvelle édition. 2002; 16-98.

[7] Direction des Parcs Nationaux. Quatrième Rapport National sur la Mise en CEuvre de la Convention sur la Diversité Biologique (République du Sénégal). République du Sénégal ; République du Sénégal. $2010 ; 133$.

[8] Thiam A, Samba S, Noba K, Ndiaye J, Diatta M, Wade M. Etude de la variation de la végétation en milieux salé et acide au Sénégal. International Journal of Biological and Chemical Sciences. 2015; 9(1): 155.

[9] Ndiaye A, Faya E, Touré M. Effets du stress salin sur la germination des graines de Gossypium hirsutum L. Journal of Applied Biosciences. 2014; 80(1): 7081.

[10] Xie J, Dai Y, Mu H, De Y, Chen H, Wu Z, Yu L, Ren W. Physiological and biochemical responses to NaCl salinity stress in three roegneria (poaceae) species. Pak. J. Bot. 2016; 48(6): 2215-2222.

[11] Collin P. L'adaptation au milieu chez les plantes vasculaires. L'Année Biologique. 2001; 40: 21-42.

[12] Fahramand M, Mahmoody M, Keykha A, Noori M, Rigi K. Influence of abiotic stress on proline, photosynthetic enzymes and growth. Int Res J Appl Basic Sci. 2014; 8(3): 257-265.

[13] ANSTS (Académie Nationale des Sciences et Techniques du Sénégal). Restauration et valorisation des terres salées du Sénégal. 2019; 56.

[14] Benidire L, Daoui K, Fatemi ZA, Achouak W, Bouarab L, Oufdou K. Effet du stress salin sur la germination et le développement des plantules de Vicia faba L. (Effect of salt stress on germination and seedling of Vicia faba L.). Journal of Materials and Environmental Science. 2015; 6(3): 840-851.

[15] Ly M, Kumar D, Diouf M, Nautiyal S, Diop T. Effet de la salinité sur la croissance et la production de biomasse de deux provenances de Jatropha curcas L. cultivés en serre. International Journal of Biological and Chemical Sciences. 2014; 8(1): 46.

[16] Ntare BR, Diallo AT, Ndjeunga J, Waliyar F. Manuel sur les techniques de production de semences d'arachide. ICRISAT, CFC, FAO. 2003; 28.

[17] Faye E, Camara M, Toure M, Mbaye A. Evaluation et amélioration du comportement de Atriplex lentiformis (Torr.) S. Watson en milieux salés au Sénégal. International Journal of Biological and Chemical Sciences. 2015; 8(4): 1697.

[18] Arnon DI. Copper enzymes in isolated chloroplasts. Polyphenoloxidase in Beta vulgaris. Plant Physiology. 1949; 24(1): 1-15.

[19] Dangue A, Gueye N, Diallo AT, Sarre IC, Ndiaye MAF, Diop, TA. Effet de la salinité sur la germination graines et la croissance des semis de treize cultivars africains de sésame (Sesamum indicum L.). European Scientific Journal. 2020; 16(15): 200-211.

[20] Lepengue AN, Mouaragadja I, Cherif M, M'Batchi B. Effet du chlorure de sodium (NaCl) sur la croissance de la roselle au Gabon. Afrique SCIENCE. 2009; 5(3): 97-110.

[21] Bahrani A, Joo MH. Response of Some Wheat (Triticum aestivum L.) Genotypes to Salinity at Germination and Early Seedling Growth Stages. World Applied Sciences Journal. 2021; 16(4): 599-609.

[22] Thouraya R, Imen I, Imen H, Riadh I, Ahlem B, Hager J. Effet du stress salin sur le comportement physiologique et métabolique de trois variétés de piment (Capsicum annuum L.). Journal of Applied Biosciences. 2013; 66(0): 5060-5069.

[23] Taïbi K, Taïbi F, Ait Abderrahim L, Ennajah A, Belkhodja M, Mulet JM. Effect of salt stress on growth, chlorophyll content, lipid peroxidation and antioxidant defence systems in Phaseolus vulgaris L. South African Journal of Botany. 2016; 105: 306-312.

[24] Dangue A, Ndiaye MAF, Guèye N, Diallo AT, Diop TA. Effect of sodium chloride on the growth and physiology of four African varieties of Sesamum indicum L. Am. J. Innov. Res. Appl. Sci. 2020; 10(6): 250-257. 
[25] Tariq A, Shahbaz M. Glycinebetaine induced modulation in oxidative defense system and mineral nutrients sesame (Sesamum indicum L.) under saline regimes. Pakistan Journal of Botany. 2020; 52(3): 775-782.

[26] Ben Ahmed H, Manaa A, Zid E. Tolérance à la salinité d'une poaceae à cycle court : La sétaire (Setaria verticillata L.). Comptes Rendus Biologies. 2008; 331(2): 164-170.

[27] Giuffrida F, Martorana M, Leonardi C. How sodium chloride concentration in the nutrient solution influences the mineral composition of tomato leaves and fruits. HortScience. 2009; 44(3): 707-711.

[28] Bekele A, Besufekad Y, Adugna S, Yinur D. Screening of selected accessions of Ethiopian sesame (Sesamum indicum L.) for salt tolerance. Biocatalysis and Agricultural Biotechnology. 2017; 9: 82-94.

[29] Srivastava N, Vadez V, Narayan Nigam SD, Upadhyaya H, Narasu L. Screening Groundnut (Arachis hypogaea L.) Germplasm for Salinity Tolerance. Journal of Genetic Resources. 2018; 4(2): 130-140.

[30] Teggar N. Etude de l'effet du stress salin sur la nodulation et quelques paramètres biochimiques et morphologiques de la lentille (Lens culinaris L.). Mémoire de magistère, Université d'Oran. 2015; 98.

[31] Saadallah K, Drevon JJ, Abdelly C. Nodulation et croissance nodulaire chez le haricot (Phaseolus vulgaris) sous contrainte saline. Agronomie. 2001; 21(6-7): 627-634.

[32] Shahid M, Ameen F, Maheshwari HS, Ahmed B, AlNadhari S, Khan MS. Colonization of Vigna radiata by a halotolerant bacterium Kosakonia sacchari improves the ionic balance, stressor metabolites, antioxidant status and yield under $\mathrm{NaCl}$ stress. Applied Soil Ecology. 2020; 158: 103809, 1-14.

[33] El-Iklil Y, Karrou M, Mrabet R, Benichou M. Effet du stress salin sur la variation de certains metabolites chez Lycopersicon esculentum et Lycopersicon sheesmanii. Canadian Journal of Plant Science. 2002; 82(1): $177-183$.

[34] Gomes MAC, Pestana IA, Santa-Catarina C, Hauser-Davis RA, Suzuki MS. Salinity effects on photosynthetic pigments, proline, biomass and nitric oxide in Salvinia auriculata Aubl. Acta Limnologica Brasiliensia. 2017; 29(9): 13.

[35] Belfakih M, Ibriz M, Zouahri A. Effet de la salinité sur les paramètres morphophysiologiques de deux variétés de bananier (Musa acuminata L). Journal of Applied Biosciences. 2013; 70(1): 5652.

[36] Diallo B, Samba SAN, Sané D. Effets de champignons MA sur la croissance et le développement de plants de ricin élevés sous contrainte saline en conditions semi-contrôlées. Revue des Energies Renouvelables. 2016; 19: 5968.

[37] Bouassaba K, Chougui S. Effet du stress salin sur le comportement biochimique et anatomique chez deux variétés de piment (Capsicum Annuum L.) À Mila /Algérie. European Scientific Journal, ESJ. 2018; 14(15): 159-174.

[38] Al-Khaliel AS. Effect of salinity stress on mycorrhizal association and growth response of peanut infected by Glomus mosseae. Plant, Soil and Environment. 2010; 56(7): 318-324.

[39] Beltrano J, Ruscitti M, Arango MC, Ronco M. Effects of arbuscular mycorrhiza inoculation on plant growth, biological and physiological parameters and mineral nutrition in pepper grown under different salinity and $\mathrm{p}$ levels. Journal of Soil Science and Plant Nutrition. 2013; 13(1): 123-141.

[40] Reddy MP, Vora AB. Salinity induced changes in pigment composition and chlorophyllase activity of wheat. Indian I. Plant Phy,Iol., XXIX. 1986; (4): 331-334.

[41] Sivasankaramoorthy S. Effect of $\mathrm{NaCl}$ salinity on germination, growth and photosynthetic pigments of Cajanus cajan L.. International Journal of Research in Plant Science. 2013; 3(4): 68-71. 